\title{
INTRODUCTORY BACKGROUND FOR LIFE CYCLE ASSESSMENT (LCA) OF PURE SILK FABRIC
}

\author{
Silvia Mara Bortoloto Damasceno Barcelos \\ State University of Maringá (UEM) - Brazil \\ E-mail: silviabortoloto@hotmail.com \\ Leila Mendes Luz \\ Federal University of Technology - Paraná (UTFPR) - Brazil \\ E-mail: leila.mendesdaluz@gmail.com \\ Ronaldo Salvador Vasques \\ State University of Maringá (UEM) - Brazil \\ E-mail: rsvasques@uem.br \\ Cassiano Moro Piekarski \\ Federal University of Technology - Paraná (UTFPR) - Brazil \\ E-mail: cassianopiekarski@gmail.com \\ Antonio Carlos Francisco \\ Federal University of Technology - Paraná (UTFPR) - Brazil \\ E-mail: acfrancisco@utfpr.edu.br \\ Submission: 08/04/2013 \\ Accept: 19/04/2013
}

\section{ABSTRACT:}

The main goal of this study is to provide an introductory background to development of the Life Cycle Assessment studies of pure silk fabric. There are not studies available on the life cycle of pure silk fabric. In this sense, was developed a scenario model for LCA application, following the methodology established by the Standard BNR ISO 14040:2009, which establishes principles and framework for an LCA study. It was considered one of the first steps in ISO, being the definition of the purpose and scope. The limits considered for the system had as a starting point the wiring step within the company, and as a final limit the stage of the finishing of the fabric, where you get the finished product. The information used in this study was collected directly from the company entitled 'Fio de Seda', a Brazilian industry. In order to construct the scenario proposed, was used the software 
Umberto ${ }^{\circledR} 5.6 \mathrm{~V}$. Acad and through it, it was possible to generate the scenario model for the production of the silk fabric. Based on this scenario, the accomplishment of the later stages is possible, as outlined in ISO 14040, thus obtaining the inventory of the LCA for the pure silk fabric, as well as its life cycle inventory assessment.

Keywords: Life Cycle Assessment (LCA); Silk fabric; Silkworm; Umberto software.

\section{INTRODUCTION}

The silk fabric (from the Latin Sericum and subsequently seta) is an animalnatured textile fiber, obtained by various cocoons that industry transforms into a continuous filament for use, being a decisive economic, social and cultural factor among civilizations since ancient times.

Being originally from China and discovered by the Chinese empress Xiling Shi around 2500-620 BC, its history is told by many thinkers concerned with this theme, among them the journalist Dinah Pezzolo de Bueno (2008), who comments: the Chinese Empress Xiling Shi, while having tea in her garden, sitting under a mulberry tree, realized that an oval-shaped cocoon fell into her cup. Due to the hot tea, a long strand of silk was loosened. It was discovered then that the cocoon could be unwound, resulting in a fine filament being capable of being woven, resulting in the silk fabric.

The notoriety of the routes spread over several countries. The city of Rome was, for a long period, the most reputable importer of silk. From 1550 the United States and Europe started the process of technological development of silk (S) manufacture. China is the largest manufacturer in the world and Brazil is among the ten largest international producers, the state of Paraná being responsible for more than $90 \%$ of the national production (SIRINGO, 2011).

Sericulture comprises the production of cocoons, which then turn into silk yarns and fabrics by the industries. Currently, sericulture is being developed with emphasis on small farms with family labor. Due to its social aspect and being a low environmental impact activity, the sericulture contributes to the sustainable development of the country. This is extremely important because organizations have to meet the demands of the sustainable development, whether they are the requirements of laws, the consumers' demand or the organization itself. 
Among the sustainability aspects, the environmental issue is widely embedded in the industrial context. As a result, it is common the adoption of environmental techniques and tools that assist in this process. Among these techniques, in recent years, the LCA is highlighted, beginning to be inserted in organizations as a way to assist in the strategic planning and decision making.

LCA assesses the environmental aspects and impacts of all stages involving the life cycle of a product, beginning with the collection of raw materials from the nature, and ending when all materials are returned to the environment, thereby enabling a global vision of the product system.

This study was implemented in the silk fabric due to three aspects. The first one was the issue of accessibility in the company studied; the second one was that the company has its completely natural manufacturing process, and the third aspect was that by searching databases, no similar and / or close studies were found, thus providing future studies in the textile sector.

Thus, this paper aims to propose a scenario for applying the Life Cycle Assessment technique in the production of silk fabric, starting from the cocoon. Next, the topics covered, such as sericulture, Bombyx mori, silk fabric, life cycle assessment, methodology, results and finally the conclusion, will be presented.

\section{THEORETICAL REFERENTIAL}

\subsection{Sericulture in Paraná, Brazil}

The rearing of silkworms, called sericulture, is a viable activity in terms of the economy in several regions of Brazil, because the climate favors the sericulture for up to ten months a year, with a satisfactory income for the producer and making Paraná State responsible for about $90 \%$ of cocoon production in Brazil (MENEGUIM et al., 2007; ZANATA et al., 2009).

The sericulture involves the cultivation of mulberry (Morus sp.), whose leaves feed the caterpillars to obtain the green cocoons; the eggs, which will give birth to the caterpillars, obtained by the industries and the creation of the caterpillars by farmers. The species Bombyx mori L. (Lepidoptera: Bombycidae), is the caterpillar of the silkworm which feeds solely on mulberry, accounting for $95 \%$ of the total production of silk used in the manufacture of different types of fabrics (PÁDUA, 2005; BUSCH, 2010). In the last decade the State of Paraná was highlighted as the biggest 
producer of green cocoons, and in the $2009 / 2010$ crop, it accounted for $92.34 \%$ of national production (BUSCH et al., 2010).

The recognition of best silk in the world happened with the implementation of a rigorous process of qualification, i.e. the larvae of silkworm are first selected. In Brazil, the silk spinning industries (BRATAC S / A. and Fujimura do Brazil) control the entire production cycle, where only the most perfect cocoons enter the production line of the most expensive and sophisticated yarn. This control is what differentiates Brazil from the world's largest producer, China, in which each step is done by an intermediary (BUSCH, 2010).

The agribusiness silk segment generates around 20,000 direct and indirect jobs, occupying an average area of 2.55 ha / producer. The productivity of caterpillars presents a performance index of kilos of cocoons / g of larvae of $3.14 \mathrm{~kg} / \mathrm{g}$. In the 2009/2010 harvest, the green cocoon production in Paraná totaled 4,099 tons covered by an area of 10,067 ha. You can find the activity in 145 municipalities in the state of Parana, which equals $76 \%$ of the state production. Parana accounted for $56.88 \%$ of the volume exported, being the main exporter of silk (BUSCH et al., 2010).

\subsection{Bombyx mori}

The silk-worm, Bombyx mori L. (Lepidoptera: Bombycidae), has similar morphological characteristics and mating ability, because it originates from the Bombyx mandarina (Theophila mandarin). Its origin can be classified and identified as Japanese, Chinese, European or Indian depending on geographical distribution. Variations in color and egg shape, strength, size, color, number of generations / year, number of moults of the caterpillar, shape, size, color and yield of cocoon are also found, depending on its origin. The qualitative and quantitative characteristics, characteristic of each breed or strains are searched in order to improve the formation of hybrids (PORTO, 2004).

The purpose of producing silkworm eggs is meeting the demand of the producers. Usually a silk moth can lay between 400 and 500 small eggs, becoming small larvae of approximately $1 \mathrm{~mm}$. The larvae are delivered to producers through companies / cooperatives, when they have the maximum size of $70-80 \mathrm{~mm}$ in length, or when they are in old age, and in a period of time of 28 days they begin producing cocoons formed by fibroin protein and sericin, which are produced by cells of the silk 
gland and expelled through the mouth of the caterpillar. Then they will be sold to companies for the production of silk. Otherwise, between 10 or 12 days, the larva which is inside the cocoon turns into a chrysalis, which becomes a moth (FERNANDEZ et al., 2005; BRANCALHÃO, 2005; OLIVEIRA, 2011).

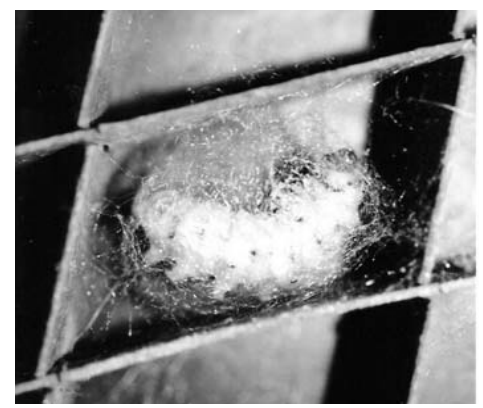

(a) Silkworm making the cocoon

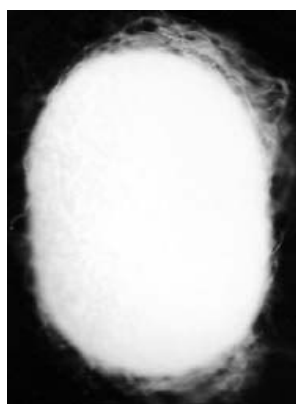

(b) Cocoon

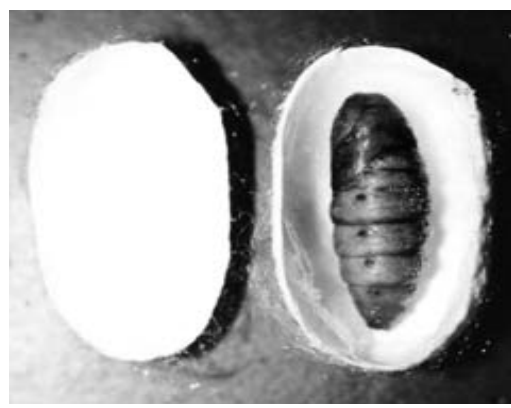

(c) Pupa or Chrysalis inside the cocoon

Figure 1: Production stage of the cocoon. Source: BRANCALHÃO, 2005

At the end of this cycle, the cocoon is ruptured by the moth, with the secretion of an alkaline liquid, softening its protein fibers. After that, it is able to restart the cycle by means of reproduction which takes 4-5 days. The larval stage consists of five ages in approximately 28 days, feeding exclusively on mulberry leaves increasing their size by 70 times compared to the initial size. It is in the last age that the larva, an adult, ceases feeding and starts the process of protein secretion, making the cocoon, which protects it for the metamorphosis which may take up to 3 days (FERNANDEZ et al., 2005; BRANCALHÃO, 2005; OLIVEIRA, 2011).

According to Brancalhão (2005, p. 01), the insects "have complete metamorphosis (the young insect is completely different from the adult one), going through four distinct morphological stages during their life cycle", according to the figures below:

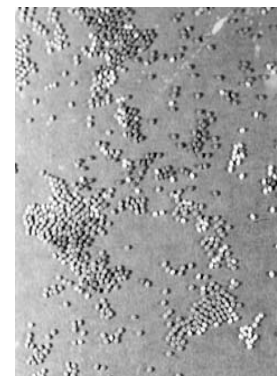

a) Egg

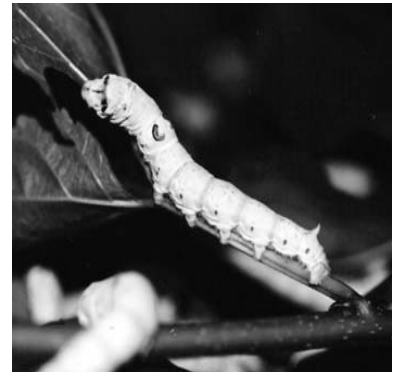

b) Caterpillar or Lar

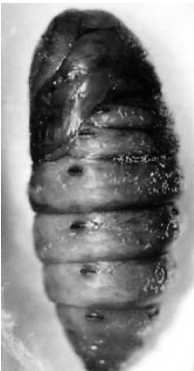

c) Pupa or Chrysalis

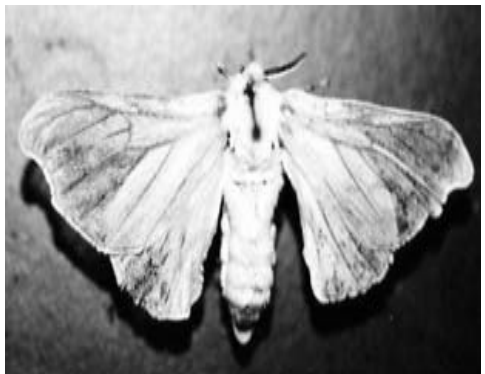

d) Moth 
Figure 2: Morphological stages.

Source: BRANCALHÃO, 2005

The silkworm caterpillar requires special care in its creation, namely, control of humidity and temperature, which have a key role in its health and productivity. The temperature should be between $20^{\circ}$ to $30^{\circ} \mathrm{C}$ and humidity ranging from $80 \%$ in the 3 rd to the 5th age, and from $60 \%$ to $70 \%$ when the caterpillar is building the cocoon. Outside this range the caterpillar reduces or even stops eating. There is also the prevention concerning the use of fungicides to prevent from diseases, thus avoiding losses in the production of cocoons. The mulberry leaf is the only food of the silkworm, for it is rich in protein, and for each stage of the caterpillar, a different type of leaf is provided (considering the stage of the mulberry trees - periods after pruning). To achieve success in quality you need a good management of the mulberry trees because their production loses in quality and quantity over the years, requiring constant investment, such as organic and chemical fertilizer (PÁDUA, 2005).

As explained in his book, Chataignier (2006) says that the silk comes from three types of harvest: natural, cultivated and wild.

\begin{abstract}
Natural, also called silk, is an outcome of the process that we mentioned above. It is extremely soft and when folded up it becomes wrinkled. This characteristic is the real test that distinguishes it from the false silk coming from synthetic fibers that do not get wrinkled.

Cultivated, spun by silkworm raised in greenhouses and is produced by the Bombyx mori larvae, a species of white moth striped with black.

Wild, also natural, however wild, producing fabrics like tussor fabrics or tussah and the wild shantung that comes from silkworm that feeds on leaves of other trees that are stronger, such as oak and hickory, especially in China and India. It is less bright than cultivated silk and is used with other fibers. The wild fiber has a brownish tinge, is thick and irregular, but it causes interesting effects in the fabrics, both for clothing and for decoration (CHATAIGNIER, 2006).
\end{abstract}

However, the most widely used one is the natural one known as silk (S). The mulberry trees are the most accurate food to have a glow in the yarn and fabric. Based on these assumptions, we must know the nature of this fiber since the birth of the moth to the spinning and fabric processing.

\title{
2.3 Silk fabric
}

Silk is a soft and lightweight fiber, it resists to all kinds of climate and can also be mixed with other types of threads, resulting in more resistant fabrics (FERNANDEZ, 2005); besides, according to the report of the textile engineer 
Ronaldo Salvador Vasquez, silk (S) has characteristics of brightness, touch and texture of good performance for use; it absorbs sweat and moisture, it has low abrasion resistance, and has extremely fine filaments. The fabrics have a soft look, nice touch and gloss. It can be used in masculine and feminine hosiery, blouses, skirts, decoration, among others. The silk fabric (S) is hypoallergenic, antibacterial and thermodynamic. A very important factor is the ease in the dyeing and in the various types of anilines which facilitates to obtain the color.

It is a natural animal-originated fiber, more resistant than other natural fibers. Its resistance is compared to that of the synthetic fibers, nylon and polyester. The fabrics made of silk have excellent finishing quality, are resistant to crease and receptive to dyeing. From the silk thread it is possible to make various kinds of fabrics such as organdy, crepe, satin, silk, chiffon, faille and hattan, among others. Silk fabric is used on shirts, dresses, blouses, ties, scarves, gloves, decorations, among others (PÁDUA, 2005; BRANCALHÃO, 2005; ORIGEM DOS TECIDOS, 2011).

A cocoon can reach from 700 to 1200 meters of filament yarn. To break the shell, i.e., remove the thread, hot water is used to dissolve the gum (sericin), then the thread is loose and can find its end. After this process the end of the thread is placed into a machine which winds the thread and makes the skein. To make the thread that is used to make fabrics, we join several hanks of yarn, thereby obtaining a thicker thread. The silk threads have some irregularities, but cannot be regarded as defective, in contrast to chemical fibers. Some fabrics of silk are obtained by threads with flames that are points that are thicker and irregular lumps. These threads are called dupions obtained from cocoons formed by two caterpillars, considered a rare and special thread, with a fairly high price (OLIVEIRA, 2011).

According to SEAB (2011), after the purchase of silk cocoons by companies, the classification process is carried out. In this process the cocoons are classified as:

- First-quality/good cocoons (these are presented clean, perfect in shape, without smudging and with chrysalis alive, tolerating only small smudges/stains/patches);

- Second-quality/pointed cocoons (they are defective, with larger patches and irregularities in the shape and skin caused by diseases and inadequate management and / or climatic factors); 
- Double cocoons (with larger size, poorly woven and consisting of two or more pupae);

- Rejects (flabby, wrinkled and sticky cocoons, with deep stains, misshapen, and stuck with large defects from the woods).

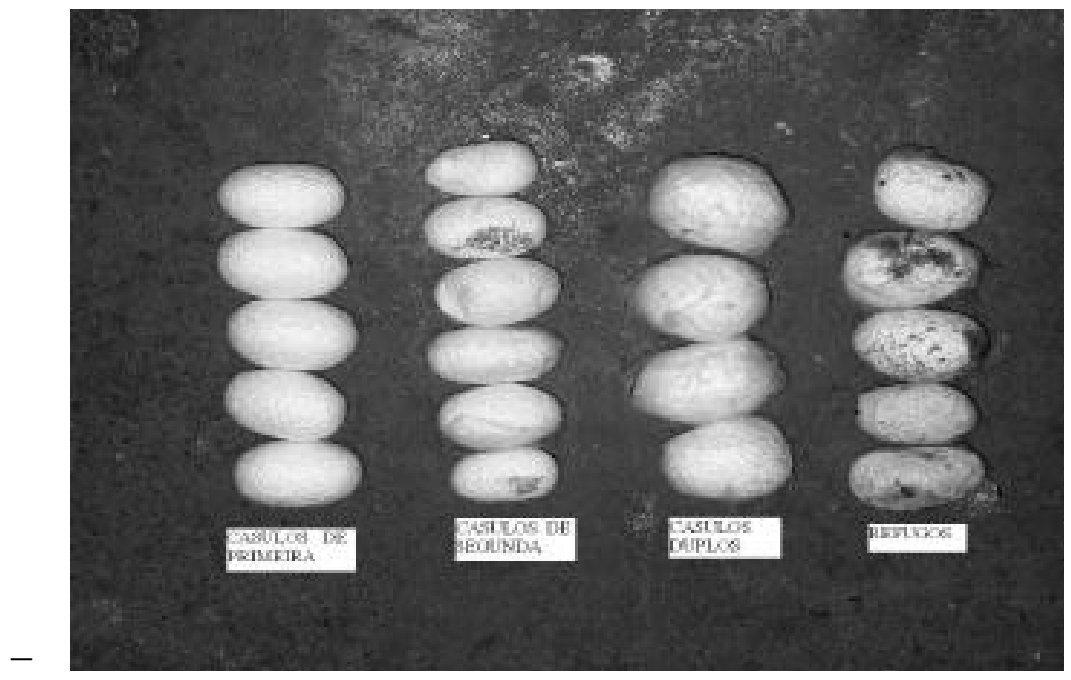

Figure 3: Classified cocoons.

Source: SEAB, 2011

The industrialization of the silk thread consists of the following processes: drying and storage, cleaning and cooking, spinning and twisting. The drying of the pods is performed to avoid the pod chrysalis to break out; it retains the commercial value and keeps the fibers in the yarn in good quality. Drying has a variation of up to 5 scales, a period lasting 6-7 hours, starting with a temperature between $125^{\circ}$ to 130 ${ }^{\circ} \mathrm{C}$ and ending between $40^{\circ}$ to $50^{\circ} \mathrm{C}$. Once dry, the pods must be stored for at least two weeks to complete the stabilization of sericin (SEAB, 2011).

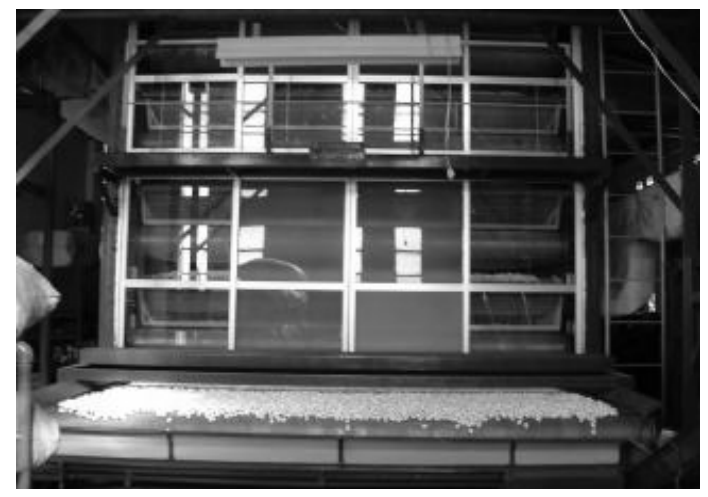

a) Front image

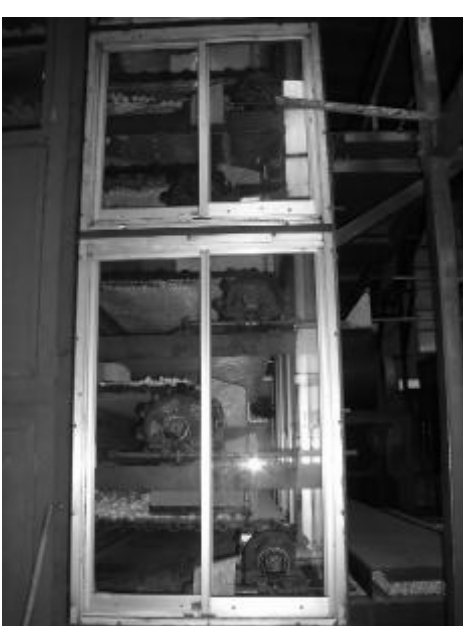

b) Side image

Figure 4: Cocoons dryer. 
Source: SEAB, 2011

To perform the cleaning, the cocoons are put into a machine to remove the anafaia (silk that the larva spins to form the cocoon). Then the cocoons are transported and placed inside the automatic cooker for unraveling. Cocoons are soaked for about 20 minutes in hot water to loosen the sericin to better loosen the fibers, giving good conditions for the spinning process (SEAB, 2011).

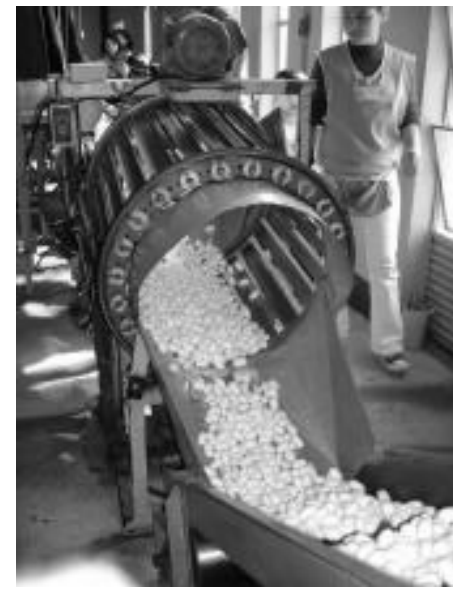

a) Cleaner to remove the coarse silk yarn spun

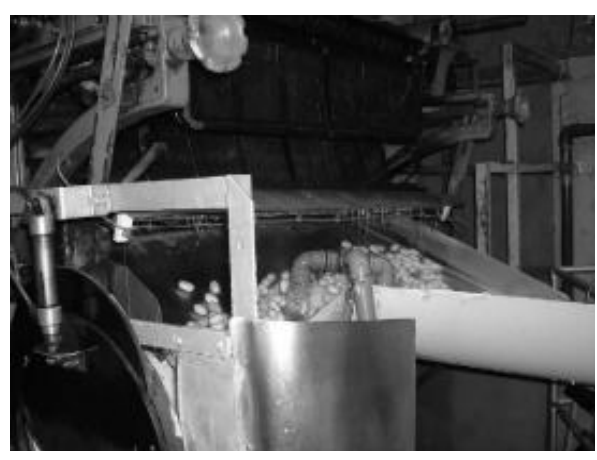

b) Cocoons way out of the "shaken" cooker

Figure 5: Cocoons cleaning and cooking. Source: SEAB, 2011

As a result, the cocoons go through automatic spinners that unwind the thread and form the silk thread. The thickness of the thread takes place in accordance with the number of cocoons used, for example, Denier $21=06$ cocoons, Denier $27=8$ cocoons, Denier $31=9$ cocoons, Denier $42=12$ cocoons. After that, the unwound wires are passed onto another reel to form the skeins, and finally, the threads are twisted (SEAB, 2011).

\subsection{Life Cycle Assessment}

Every product causes some kind of impact on nature. These impacts according to Robles Junior and Bonelli (2006), do not begin in the post-consumption stage but at the time the materials are extracted from their sources in nature and ends with the final output in the environment, as pollution, waste and emissions. The effect on the environment occurs in all stages of processing, production, packaging and use.

The LCA is then a tool used to quantify and interpret environmental flows to and from the environment, involving the capture, validation, evaluation, verification 
and interpretation of environmental data including the purchase of raw materials, manufacturing, transportation, use, maintenance and final disposal (ATHENA SUSTAINABLE MATERIALS INSTITUTE, 2009).

Thus, LCA evaluates the environmental aspects and impacts caused by the product throughout its life cycle including, in accordance with ISO 14040 (2009), four phases: purpose and scope definition, inventory analysis, impact assessment and interpretation.

According to Guinée (2001) in the phase of purpose and scope definition, the initial choices are made, determining the work plan of the LCA, and the main characteristics of the study are established. Therefore, in this period of the study, it should be defined the function of the system studied, the functional unit, the process units and system boundaries (PEREIRA, 2008). Each of these items is defined by ABNT (2009) as:

- Product System: Set of processing units, connected materially and energetically, which performs one or more defined functions. The function of the system is the intended product use;

- Functional unit: quantified performance of a product system for use as a reference unit in a life cycle evaluation study;

- Process units: Lower portion of a product system for which data are collected when a life cycle assessment is carried out;

- System Boundaries: Interface between a product system and the environment or other product systems.

In practice, the scope should be delimited through the system boundaries, which separate the studied system from the environment and other product systems (SANTOS, 2002). Thus, the system is subdivided into a number of process units.

In the phase of the Life Cycle Inventory Assessment (LCIA) all inputs and outputs of each process unit are identified in order to assess which are most significant for modeling the data (COSTA, 2007). Chehebe (1997) reports that at this stage, care must be taken, such as: the design of specific flow charts that show all the process units, including the interrelations between them; and the detailed 
description of each process unit and the list of data categories associated with each one of them.

Subsequently, the data collected are grouped considering the environmental loads or the items to be evaluated, and in the functional unit. Thus, the product of the life cycle inventory is a list containing the volume of consumed energy, materials and quantities of pollutants emitted to the environment (PEREIRA, 2008). It all results in the quantification of environmental aspects associated with the life cycle of the product.

In the next phase of the LCA, the impact assessment, inventory data are associated with specific environmental impacts, where the choice of impacts evaluated and methodologies used and the level of details depends on the purpose and scope of the study (ABNT, 2009, p.7). UNEP (2003) presents the impact categories in which the inventory data can be sorted, separating them into input and output categories, relating to each of them the potential indicators generated. These categories are shown in Table 1.

Table 1: Examples of Life Cycle Impact categories

\begin{tabular}{|c|c|}
\hline Impact categories & Possible indicator \\
\hline \multicolumn{2}{|l|}{ Categories related to Entry } \\
\hline Extraction of abiotic resources & Lack of resources \\
\hline Extraction of biotic resources & Lack of resources, considering the replacement rate \\
\hline \multicolumn{2}{|l|}{ Categories Related output } \\
\hline Climate change & $\begin{array}{l}\mathrm{Kg} \text { of } \mathrm{CO} 2 \text { as a unit of equivalence for the Global Warming } \\
\text { Potential }\end{array}$ \\
\hline Stratospheric ozone depletion & $\begin{array}{l}\mathrm{Kg} \mathrm{of} \mathrm{CFC-11} \mathrm{as} \mathrm{a} \mathrm{unit} \mathrm{of} \mathrm{equivalency} \mathrm{to} \mathrm{the} \mathrm{potential} \\
\text { for ozone depletion }\end{array}$ \\
\hline Human toxicity & Potential toxicity human \\
\hline Ecotoxicity & Potential for Eco-toxicity \\
\hline Formation of photo-oxidants & 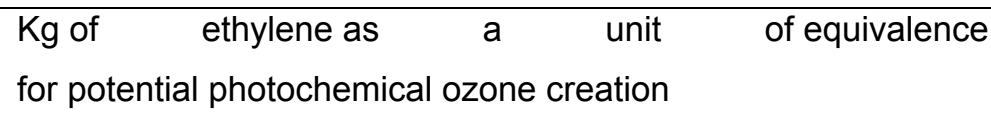 \\
\hline Acidification & $\begin{array}{l}\text { Release of } \mathrm{H}+\text { as a unit of equivalence for the acidification } \\
\text { potential }\end{array}$ \\
\hline Nitrification & $\begin{array}{l}\text { Total macro-nutrients as the unit of } \\
\text { for potential Nitrification }\end{array}$ \\
\hline
\end{tabular}

In the interpretation phase according to ISO 14040 "the interpretation is the phase of LCA where the findings of the inventory analysis and impact assessment 
are combined, consistently with the purpose and scope defined in order to reach conclusions and recommendations" (ABNT, 2009, p.7).

The findings of the study are confronted with the purpose and scope of the study in order to analyze the quality of the data and explain the limitations of the study carried out (COSTA, 2007). Thus, the findings of this interpretation can become useful conclusions and recommendations for managers, consistently with the purpose and scope of the study (ABNT, 2009).

According to Valt (2004) the conclusions reached after reviewing the results allow the identification of critical points in the lifecycle of the product that need improvement, allowing the implementation of production strategies, such as replacement and recovery of materials and redesign or replacement of processes, aimed at environmental preservation.

Thus the main applications of LCA according to Guinée (2001) are: to analyze the origins of the problems related to a particular product; allow improvements by comparing variants of a particular product; promote the development of new products; enable the choice from a range of comparable products.

Thus the LCA provides information that can be used to benefit the organization.

\section{METHODOLOGY}

This research is classified as applied, exploratory, qualitative, literature and a case study. The methodology followed in the study was established by ISO 14040:2009, which establishes principles and framework for an LCA study.

As this study deals with the proposal of a scenario for application of LCA in the production of silk, it was considered the first step described in ISO quoted above, defining the purpose and scope.

The data required for the study were obtained by formal interview, firstly identifying process units forming part of the system.

To construct the scenario, the limits considered for the system had as a starting point the wiring step within the company, in which all process units of the system were identified and as a final limit the step of finishing the fabric, where you 
get the finished product and not considering the later stages of dyeing, distribution, processing, use, disposal, among others.

The data processing and modeling were carried out with the support of the software system Umberto v 5.6 academic.

\section{RESULTS}

As presented in the review and reported by Costa (2007) in preparation of the life cycle inventory all inputs and outputs of each process unit are identified, thus identifying which are most significant for modeling the data. Moreover, according to Chehebe (1997) one of the precautions to be taken is the construction of specific flow charts that show all the process units, including the interrelations between them.

Thus, from the data collected a flowchart was prepared containing the processes considered. The picture obtained for the system can be seen in Figure 6. For the construction of this scenario the inputs and outputs related to the process units were considered: spinning, drying, twisting, weaving and finishing.

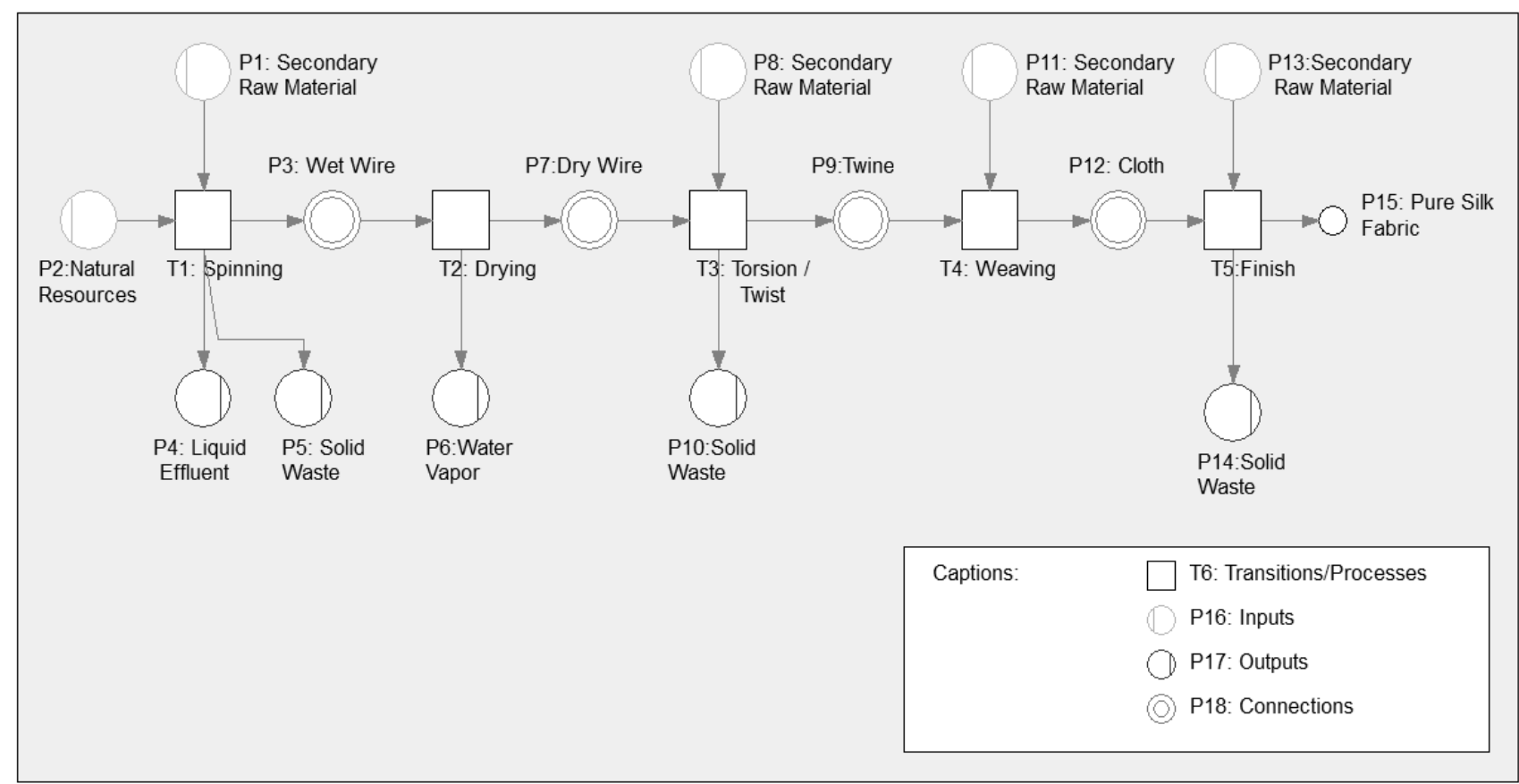

Figure 6: Scenario of the production of woven silk.

Source: survey data, 2011

This scenario can be used as support for the later stage of the LCA, the development of life cycle inventory for the silk fabric. It is essentially the collection of the data and the objective is to perform mass and energy balances to quantify all the materials and energy inputs, as well as wastes and emissions from the system that 
cause the environmental burdens (BENEDETTO, KLEMES, 2009). Inputs are raw materials, energies, water, etc. Outputs are the products and co-products, emission to air, water and soil, and wastes (ROY et al., 2009).

Since, for the collection of data for each processing unit can be considered a form used, which are quantified all inputs and outputs. A model for data collection is presented in Table 2.

Table 2 - Form for data collection.

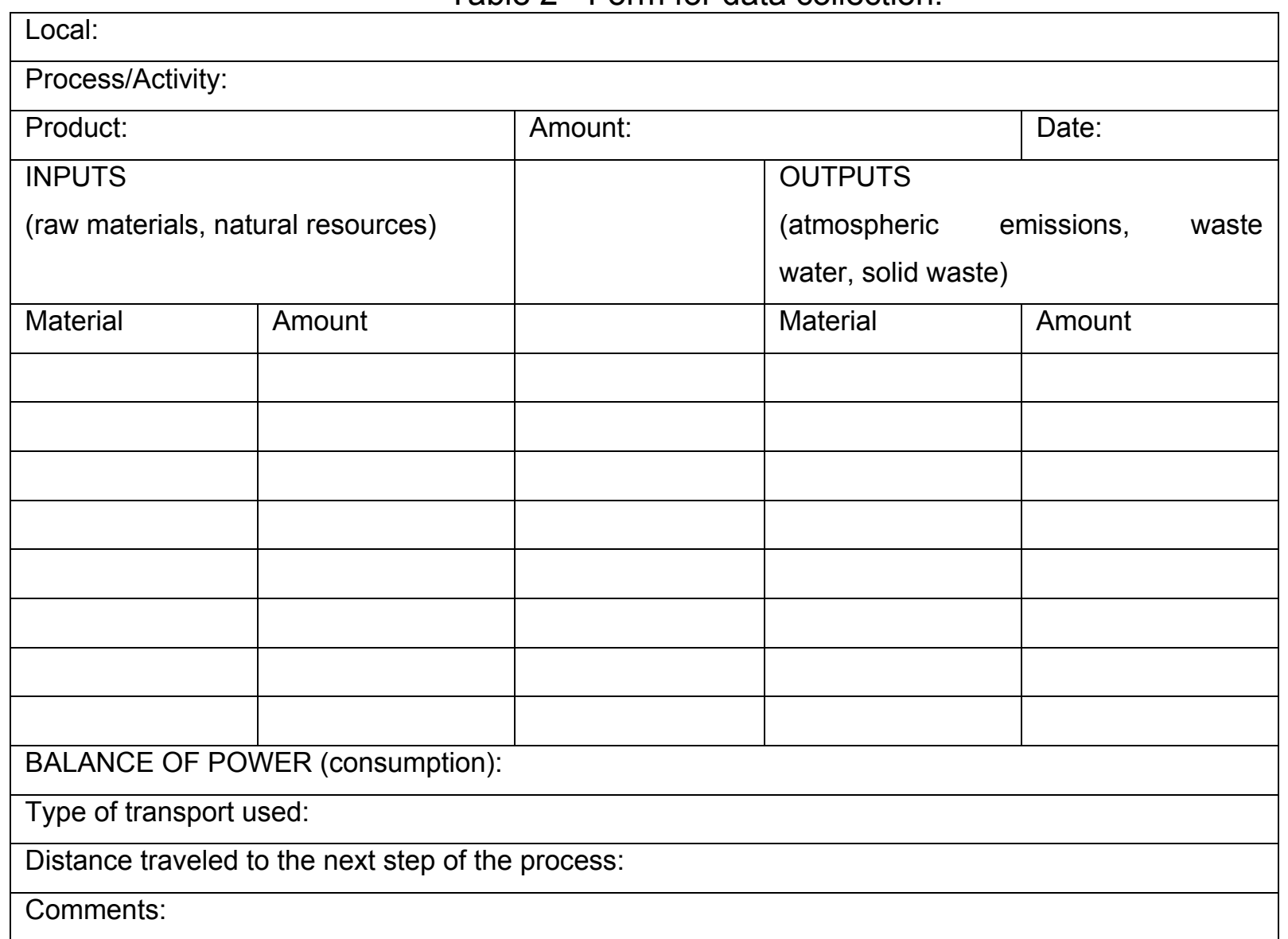

Source: Prado, 2007

An example of a functional unit showed in Table 2 that can be adopted for a study of LCA is of $1 \mathrm{Kg}$ of cocoons to obtain the finished fabric.

After the inventory phase, occurs the impact assessment in LCA. It is consists of the following elements: classification, characterization, normalization and valuation (Roy et al., 2009). The phase is based on the aggregation of the environmental impacts quantified in the inventory analysis into a limited set of recognizable impact categories (e.g. climate change, global warming, ozone depletion, acidification, eutrophication) (Benedetto and Klemes, 2009). 
And the last stage purpose of an LCA is to draw conclusions that can support a decision or can provide a readily understandable result of an LCA (ROY et al., 2009). Interpretation is a procedure to evaluate the information from the inventory analysis and impact assessment of the system and to propose conclusions from all of the previous results of the study (BENEDETTO; KLEMES, 2009).

\section{CONCLUSIONS}

Considering the study above on the activity of sericulture, silkworm and LCA, a prominent point is the development of production of silk, which involves the social aspect and low environmental impact, as well as the contribution for an industrial system that involves sustainable development. The fulfillment of legal requirements, the consumers' demand and the organization that the production itself requires are of great importance.

Tools and techniques related to the environment assist production processes associated with the aid of designed strategies, business management and promoting green innovations (PIEKARSKI et al., 2013) although LCA application.

Thus, this paper presents a scenario model for the evaluation of the LCA for the silk fabric. Based on this scenario the fulfillment of the later stages is possible, as outlined in ISO 14040, thus obtaining the inventory of LCA for the silk fabric, as well as its evaluation.

\section{ACKNOWLEDGEMENTS}

To Fundação Araucaria and CAPES for the financial support, and the company that received us and collaborated with the accomplishment of this research.

\section{REFERENCES}

ASSOCIAÇÃO BRASILEIRA DE NORMAS TÉCNICAS (ABNT) (2009a) NBR ISO 14040: Gestão Ambiental - Avaliação do ciclo de vida - Princípios e estrutura. Brasil.

ASSOCIAÇÃO BRASILEIRA DE NORMAS TÉCNICAS (ABNT) (2009b) NBR ISO 14044: Gestão Ambiental - Avaliação do ciclo de vida - Requisitos e Orientações. Brasil.

ATHENA SUSTAINABLE MATERIALS INSTITUTE. Available: http://www.athenasmi.org/what-we-do/lca-data-software/. Access: 03th November, 2009.

BENEDETTO, L. D., Klemes, J. (2009). The Environmental Performance Strategy Map: an integrated LCA approach to support the strategic decision-making process. Journal of Cleaner Production, v. 17, n. 10, p. 900-906. 
BRANCALHÃO, R. M. C. (2005) Bicho-da-seda. Available:

http://www.seab.pr.gov.br/arquivos/File/complexo_da_seda/b_mori.pdf. Access: 15th April, 2011.

BUSCH, A. P. B. (2010) Sericicultura. Available:

http://www.seab.pr.gov.br/arquivos/File/deral/Prognosticos/seda_2010_11.pdf. Access: 15th April, 2011.

BUSCH, A. P. B.; FREITAS, M. C. D. O.; MAZZAROTTO, M. (2010) Relatório Takii: perfil da sericicultura no Estado do Paraná. Available:

http://www.seab.pr.gov.br/arquivos/File/deral/relatorio_takii_2009_10.pdf. Access: 17th April, 2011.

CHEHEBE, J. R. B. (1997) Análise do ciclo de vida de produtos: ferramenta gerencial da ISO 14000. Rio de Janeiro: Qualitymark.

COSTA, M. S. V. (2007) 0 enfoque de ciclo de vida como estratégia para a gestão sustentável: um estudo de caso sobre pneus. Dissertação (Mestrado em Ciências em Engenharia de Produção). Rio de Janeiro: UFRJ.

CHATAIGNIER, G. (2006) Fio a fio: tecidos, moda e linguagem. São Paulo: Estação da Letras.

FERNANDEZ, M. A.; CIFEERI, R. R.; PATUSSI, E. V.; PEREIRA, M. F.; FELIPES, J.; BRAVO, J. P.; ZANATA, D. B.; GOUVEIA, F. S.; BALANI, V. A. (2005) A utilização da biotecnologia na sericicultura brasileira. Biotecnologia Ciência \& Desenvolvimento, n. 35, p. 52-57. Available:

http://www.biotecnologia.com.br/revista/bio35/bio_35.pdf. Access: 04th April, 2013.

GUINÉE, J. B; GORÉE, M; HUPPES, R, H. G.; KLEIJN. R.; KONING, A.; SLEESWIJK, L. O. A. W.; SUH, S.; HAES, H. A. U. (2001) Handbookon Life Cycle Assessment Operational Guide to the ISO Standards. Publisher: Kluwer Academic Publishers, Dordrecht.

MENEGUIM, A. M.; LOVATO, L.; SILVA, R. Z.; YAMAOKA, R. S.; NAGASHIMA, G. T.; PASINI, A. (2007) Influência de cultivares de Amoreira Morus spp. Sobre a produção e qualidade de casulos de bicho-da-seda, Bombyx mori L. (Lepidoptera: Bombycidae). Neotropical Entomology, v.3, n. 5, p. 670-674.

OLIVEIRA, M. H. (2011) Seda, um tecido nobre. Available:

http://www.bndes.gov.br/SiteBNDES/export/sites/default/bndes_pt/Galerias/Arquivos/ conhecimento/setorial/is11seda.pdf. Access:18th April, 2011.

ORIGEM DOS TECIDOS. (2011) Tipos e origens dos tecidos. Available: http://tecidos.pbworks.com/w/page/20358299/Origem-dos-tecidos. Access: 20th April, 2011.

PÁDUA, O. S. (2005) A origem da sericicultura. Available: http://www.seab.pr.gov.br/arquivos/File/complexo_da_seda/folder_origem.pdf. Access: 26th April, 2011. 
PEREIRA, C. L. F. (2008) Avaliação da Sustentabilidade Ampliada de Produtos Agroindustriais: estudo de caso suco de laranja e etanol. Tese (Doutorado em Engenharia de Alimentos). Campinas: Universidade Estadual de Campinas.

PEZZOLO, B. D. (2008). Tecidos: história, tramas, tipos e uso. São Paulo: SENAC SP.

PIEKARSKI, C. M.; LUZ, L. M; ZOCCHE, L. FRANCISCO, A. C.(2013). Life Cycle Assessment as Entrepreneurial Tool for Business Management and Green Innovations. Journal of Technology Management \& Innovation, v. 8, n. 1, p. 4453.

PORTO, A. J.; OKAMOTO, F.; CUNHA, E. A.; OTSUK, I. P. (2004) Caracterização de oito raças do bicho-da-seda (Bombyx mori L.). Ciência Rural, v. 34, n. 1, p. 259264.

PRADO, M. R. (2007). Análise do inventário do ciclo de vida de embalagens de vidro, alumínio e pet utilizadas em uma indústria de refrigerantes no Brasil. Tese (Doutorado em Tecnologia de Alimentos). Curitiba: Universidade Federal do Paraná.

ROBLES JUNIOR, A.; BONELLI, V. V. (2006) Gestão da qualidade e do meio ambiente: enfoque econômico, financeiro e patrimonial. São Paulo: Editora Atlas.

ROY, P., Nei, D., Orikasa, T., Xu, Q., Okadome, H., Nakamura, N., Shiina, T. (2009). A review of life cycle assessment (LCA) on some food products. Journal of Food Engineering, v. 90, n. 1, p. 1-10.

SANTOS, L. M. M. (2002) Avaliação ambiental de processos industriais. Ouro Preto: ETFOP.

SEAB - Secretaria de Estado da Agricultura e do Abastecimento. (2011) O Processo de Industrialização do Fio da Seda. Available:

http://www.seab.pr.gov.br/arquivos/File/complexo_da_seda/industrializacao_fio_seda .pdf. Access: 25th April, 2011.

SIRINGO, J. (2011) A Magia que veio do Oriente. Revista Magazine Lupo, v. 6, n. 17 , p. 14-17.

UNEP - UNITED NATIONS ENVIRONMENT PROGRAMME (2003) Evaluation of environmental impacts in life cycle assessment. Available:

http://www.unep.fr/scp/publications/details.asp?id=3234. Access: 06th November, 2009.

VALT, R. B. G. (2004) Análise do ciclo de vida de embalagens de pet, de alumínio e de vidro para refrigerantes no Brasil variando a taxa de reciclagem dos materiais. Dissertação (Mestrado em Engenharia). Curitiba: UFPR.

ZANATTA, D. B.; BRAVO, J. P.; BARBOSA, J. F.; MUNHOZ, R. E. F.; FERNANDEZ, A. M. (2009) Avaliação de características economicamente importantes de dezesseis 
linhagens parentais do bicho-da seda Bombyx mori L (Lepidoptera: Bombycidae). Neotropical Entomology, v. 38, n. 3, p. 327-331. 